\title{
Besleria lutea, Linn., a New Example of Water.calyx.
}

\author{
MONTAGU DRUMMOND, B.A., F.L.S., \\ Lecturer in Plant Pkysiology, University of Glasgow.
}

$B$ ESLERIA lutea, Linn., is a small Gesneraceous shrub, which grows in moist mountain woods in Jamaica and several other West Indian islands, as well as in north-eastern South America. It occurs plentifully in the vicinity of Cinchona, in the Blue Mountains of Jamaica, where the peculiar swollen appearance of its calyx attracted my attention during my stay at the Hill Garden in the late summer of I9I3. A closer examination of flower-buds showed that the tube of the gamosepalous caly $x$ is greatly inflated, especially towards its base, so that the corolla and essential organs-. which lag far behind the calyx in development-are, at this stage, enclosed in a bell-shaped cavity of considerable size. In the bud, this cavity is completely filled with a clear watery liquid, which is prevented from escaping, chiefly by the circumstance that the closely apposed, connivent lobes of the calyx-limb are slightly twisted around one another. The margins of the calyx-lobes further interlock by means of cellular sutures.

The calyx-cavity remains filled with ' water' after the corolla has burst through the tip of the calyx, and even after the flower is fully open. The application of gentle pressure to the calyx of a flower in full bloom causes liquid to exude from its apex. During the ripening of the fruit the calyx becomes still more distended, and assumes a globose shape, thus keeping pace with the enlargement of the ovary to form a spherical berry. Some considerable time before the fruit matures, liquid disappears entirely from the calyx-cavity, which thenceforth contains air.

The calyx is a somewhat massive structure, but its anatomical construction is simple. The outer epidermis is small-celled, and bears scattered simple hairs composed of from one to three thick-walled, cylindrical cells, the terminal one of which tapers to a point. A few stomata are present on the outside of the young calyx, but these are very soon replaced by numerous small lenticel-like structures. The peripheral parts of the mesophyll consist of closely-packed, slightly collenchymatous elements; the central portion is thin-walled and well provided with intercellular spaces. The inner epidermis is large-celled, quite devoid of stomata, and bears numerous large capitate

\footnotetext{
[Annals of Botany, Vol. XXXIV No. CXXXVI. October, 1980.]
} 
glands all over its surface, but especially in the vicinity of the vascular bundles, which lie at the adaxial edge of the central mesophyll. These glands agree in general structure with the trichome-hydathodes of Clerodendron Minahassae, Teijsm. and Binn., as described by Koorders (Ann. Jard. Buit., xiv, 1897), but offer some features of interest which will be dealt with in a subsequent communication.

There is every reason to suppose that the liquid contained in the calyxtube is secreted by the capitate glands of the inner calyx-epidermis. In all the cases of water-calyx previously described, glandular trichomes occur in a similar position, although in certain of the instances investigated by Koorders (1.c.), e.g. Parmentiera cereifera, Seem., and Crescentia Cujete, Linn., the outer epidermis of the corolla is also provided with similar structures. The corolla of Besleria lutea, Linn., possesses no features suggestive of a special water-secreting capacity, and the relatively feeble development of its vascular system tells against any such activity on its part. The calyx, on the other hand, has a well-developed system of vascular strands, the glandular hairs are most plentiful in the neighbourhood of these strands, and the intervening parenchyma tends to arrange itself in rows radiating from the bundles towards the glanduliferous strips of the inner epidermis.

The physiological or ecological value of water-calyces is obscure. Koorders (l.c.) regards water-calyx as a device for protecting the other parts of the flower against desiccation. That may quite probably be the function, or one of the functions, of the calyx in such a tree as Spathodea campanulata, Beauv., which, as Treub (Ann. Jard. Buit., viii, I890) has remarked, bears the large flowers massed together at the ends of its branches, where they are regularly exposed to intense insolation. This explanation is, however, not so readily applicable to Besleria hutea, Linn., which, in Jamaica, inhabits a very humid and only moderately hot region, and which, moreover, is generally to be met with in the shade of taller shrubs or trees. I found it, for example, growing luxuriantly on the banks of the Mabess River, in a deep, densely wooded valley; where the atmospheric humidity is so constantly high that epiphyllous growth is extraordinarily prevalent. Lagerheim (Ber. d. deutscl. bot. Ges., ix, I89I) has suggested that water-calyx may serve as a protection against perforation of the corolla by humming-birds and other nectar thieves. At Cinchona, open flowers of Besleria lutea, Linn., are very frequently injured by some animal, which lacerates the limb of the corolla; but I did not observe the plant being visited either by humming-birds (two species of which are very common in the neighbourhood) or by any other animal.

I had no opportunity of determining the chemical composition of the liquid secreted by the calyx, but, according to my field-notes, it is clear and slightly mucilaginous, when fresh, and has a distinctly saline taste. 
So far as I am aware, the present note is the first record of the occurrence of a water-calyx in the Natural Order Gesneraceae. The closely allied Bignoniaceae, however, include most of the plants with water-calyces so far described. The genus Besleria comprises some sixty species, spread over the West Indies and Central and South America, more than a quarter of the whole being natives of Brazil. Few of these are to be met with in cultivation, as their flowers are generally small and dully coloured, and the habit of the plants is ungraceful. B. Imr ay, Hook., is figured in 'Bot. Mag.', Tab. 634I, and its calyx, as depicted there, strongly recalls that of B. luted, Linn. A comparative study of the calyx within this large genus would in all probability throw fresh light on the origin and significance of watercalyces in general.

I wish to record my indebtedness to the Royal Society of London for a grant in aid of the expedition on which the material of Besleria lutea, Linn., was obtained. 


\section{$2 \mathrm{BHL}$ Biodiversity Heritage Library}

Drummond, Montagu. 1920. "Besleria lutea, Linn., a new example of water-calyx." Annals of botany 34, 551-553.

https://doi.org/10.1093/aob/os-34.4.551.

View This Item Online: https://www.biodiversitylibrary.org/item/236972

DOI: https://doi.org/10.1093/aob/os-34.4.551

Permalink: https://www.biodiversitylibrary.org/partpdf/320307

\section{Holding Institution}

Smithsonian Libraries

\section{Sponsored by}

Biodiversity Heritage Library

\section{Copyright \& Reuse}

Copyright Status: Not in copyright. The BHL knows of no copyright restrictions on this item.

This document was created from content at the Biodiversity Heritage Library, the world's largest open access digital library for biodiversity literature and archives. Visit BHL at https://www.biodiversitylibrary.org. 